\title{
ПРОБЛЕМАТИКА ПОЛИТИКО-ПРАВОВЫХ ИНСТИТУТОВ В КОНТЕКСТЕ СОВРЕМЕННОЙ ФИЛОСОФСКОЙ КОМПАРАТИВИСТИКИ
}

\author{
Равочкин Никита Николаевич, \\ nickravochkin@mail.ru \\ Кемеровский государственный сельскохозяйственный институт, \\ Россия, 650056, г. Кемерово, ул. Марковцева, 5
}

Равочкин Никита Николаевич, кандидат философских наук, доцент кафедры гуманитарноправовых дисциплин Кемеровского государственного сельскохозяйственного института.

В статье рассматривается проблематика политико-правовых институтов в контексте исследований, связанных с относительно новым разделом научного знания - философской компаративистикой. Актуальность исследования подтверждается высоким уровнем ответственности, который возлагается на рассматриваемые институты в целях обеспечения ими социального порядка. Таким образом, сопоставительные исследования выглядят крайне необходимыми при изучении идейной детерминации схожих институтов в различных типах общества и государства. Предметом исследования являются перспективные направления для сравнительных исследований современных политико-правовых институтов. Объектом исследования выступают современные политико-правовые институты. Цель исследования заключается в обозначении поля проблематики политико-правовых институтов в контексте исследований по философской компаративистике. Для достижения поставленной цели используется собственная синтетическая методология, включающая общенаучные, философские и междисциплинарные методы (акторно-сетевая теория, меметика, мир-системный подход, социальный реализм). Представлены определения философской компаративистики. Произведено включение политико-правовых институтов в данный раздел, для чего автором предлагается собственная модель политико-правового института, дополняющая модель У. Кротти. Обозначены основные направления исследований политико-правовых институтов: проблематика партий, конституций, ценностей с привязкой к различным государствам и регионам.

Ключевые слова: Политико-правовой институт, идеи, философская компаративистика, ценности, общество, государство, мир.

\section{Введение}

Социальная динамика коренным образом сказывается на трансформациях политико-правовых институтов, сформированных в реалиях контекста того или иного общества. Особую глубину, интенсивность и масштабность трансформационные процессы приобретают в начале третьего тысячелетия, что, безусловно, связывается с глобализацией. Основными маркерами данного мегатренда являются следующие проявления: существенные изменения в материальной и духовной культуре, повышение транспарентности между границами привычных моделей устройства различных сфер общественной жизни, усиление роли цифровизации и т. д. Влияние указанных процессов приводит к соответствующей структурной и функциональной перестройке существующих политико-правовых институтов, а также способствует появлению новых социальных установлений. 
На сегодняшний день раскрытие логики и определение сущности социальных трансформаций на различных уровнях общественного бытия все чаще являются объектом исследований в современном философском и междисциплинарном дискурсах. В то же время сегодня интересующая нас проблематика трансформаций политико-правовых институтов разрабатывается зарубежными учеными в рамках философской компаративистики. Несмотря на то, что в рамках данного направления накоплен внушительный корпус работ, посвященных изучению трансформаций политико-правовых институтов современности, отечественные ученые, как правило, достаточно редко опираются на полученные зарубежными коллегами результаты при проведении собственных исследований. Между тем, синтез результатов исследований отечественных и зарубежных ученых, по мнению автора, позволит не только несколько минимизировать существующие и не всегда высказываемые противоречия, но и представить более полную картину трансформаций политико-правовых институтов. Второй позитивный аспект, раскрываемый упомянутой картиной, касается прогнозирования и последующего преодоления проблем, с которыми данные институты сталкиваются сегодня. На наш взгляд, все это позволит осуществлять многомерный сравнительный анализ, итоги которого поспособствуют пониманию причин и возможных траекторий трансформаций, что, собственно, и обусловливает актуальность заявленной темы исследования.

Цель исследования можно сформулировать следующим образом: обозначить поле проблематики политико-правовых институтов в контексте исследований по философской компаративистике.

\section{Философская компаративистика как область научного познания}

Логика проведения данного исследования прежде всего требует обращения к самому понятию «философская компаративистика». Данное направление научных исследований является достаточно молодым среди множества предметных областей философии, а его институционализация происходит в 20-60-х гг. XX в. [1, с. 17]. Становление компаративистики обусловлено диффузией философских знаний среди мировых регионов. Следствием отсюда становится ослабление господства Европы («европоцентризм») как доминирующего региона сосредоточения интеллектуальных сетей. Это находит своё отражение в развитии плюрализма систем взглядов и аксиологических модусов, предлагающих миру варианты рассмотрения проблем через, например, интуитивизм, прагматизм, рационализм, а также многие другие концепции, в том числе и синтетические.

Теперь стало очевидным, что философия имеет и так называемые «неевропейские голоса», поэтому в связи с усилением глобализационных процессов на арену мировой мысли выходят «национальные» теории и учения. Осознание того, что мир не сводится и не может быть сведен исключительно к европейской цивилизации, как никогда прежде артикулирует многообразие способов решения философских вопросов. Так, одной из главных задач, возникающих и стоящих сегодня перед обществом, «по умолчанию» является сохранение этой полифонии и многообразия. По мнению автора, одной из удачных дефиниций, определяющей философскую компаративистику, становится ее понимание в качестве теоретической области познания, которая занимается рассмотрением процессов глобализации, влекущих за собой интеграцию культур и появление «глобальной деревни» (М. Маклюэн) [2, с. 421]. Также следует уточнить практическую направленность данного направления философских исследований, которое посредством ведения диалогов и организации эффективных коммуникативных взаимодействий стремится воплотить общемировое демократическое сотрудничество и тем самым противодействует нацеленным на единоличную гегемонию олигархическим или имперским режимам [3]. 
По словам А.С. Колесникова, предметом данной области (по)знания выступают, «не только философские культуры великих цивилизаций («философских цивилизаций»), но и проблемы, связанные с различиями и сходством между ними» $[4$, с. 20]. Таким образом, в центре внимания философской компаративистики оказывается плюрализм проблем: идеи синтеза национальных философских систем, проблемы их самоидентификации и самобытности, расширение горизонтов философской мысли. Безусловно, в социально-философский аспект включается проблематика трансформаций национальных обществ и политико-правовых институтов, регулирующих жизнедеятельность национальных государств и обеспечивающих их порядок.

\section{Подходы к пониманию политико-правовых институтов}

Прежде всего, нам хотелось бы отметить, что политико-правовые институты в своем современном понимании, несмотря на их появление еще в нововременных концепциях, стали рассматриваться в контексте философской компаративистики лишь со второй половины прошлого века. Разумеется, что на протяжении этого периода происходит дифференциация позиции к их пониманию. Так, наиболее распространенные подходы к постижению сущности политико-правовых институтов можно разделить на четыре направления:

1. «Исторический». Сосредоточивается на генезисе институтов, связанном с историческим переходом от потестарных обществ к первым формам государственности, при котором традиции и обычаи воспринимаются в качестве пережитков, т. е. являются признаками отсталости социума и должны быть немедленно устранены (в том числе и насильственным путем) для улучшения общества и обеспечения его прогрессивного развития $[5,6]$.

2. «Атрибутивный». Рассматриваемые установления не имеют для социума сколько-нибудь приоритетного значения, поскольку являются своеобразными дополнениями к экономическим институтам, поэтому редко заслуживают серьезного рассмотрения [7].

3. «Социокультурный». Политико-правовые институты являются неприкосновенными, поскольку каждая из всего множества национальных культур содержит уникальные параметры их функционирования, отражающие итоги интеллектуального творчества в исторической ретроспективе в зависимости от эпохи [8].

4. «Менеджериальный». Инициируемые и принимаемые этими структурами решения в конкретном властном, к примеру, демократическом ключе, являются тем звеном, которое определяет приоритеты этих институтов как ведущих детерминант экономических достижений, технического прогресса, богатой и разнообразной культуры, в общем и целом - способствует повышению уровня жизни в том или ином государстве [9].

В то же время на основании синтеза этих и имеющихся в работах зарубежных авторов других подходов в последние годы все болышее распространение получает обобщающее понимание политико-правовых институтов. В соответствии с попытками дать всестороннее освещение рассматриваемого типа социальных структур возникает их определение как динамических универсальных конструктов, имеющих ярко выраженную властную природу, аксиоматически связанных с общественным успехом, изменяющихся в зависимости от различных (контекстуальных) условий, которые следует использовать для достижения инструментальных и внутренних целей [10]. Иначе говоря, сегодня практики функционирования политико-правовых институциональных образований одновременно детерминированы национально, а также представляют собой универсальные модели. Универсализм объясняется регулярными обращениями властей к их использованию как относительно проверенных и эффективных способов достижения социальной эволюции. Таким образом, бесспорным будет выглядеть момент о неизменности факта вовлеченности политико-правовых установлений во все процессы, которые протекают в обществе. На основании этого предложена некоторая модель данного института в рамках абстрактного социального пространства, которая бы дополняла ставшую «классической» модель У. Кротти [11] (см. рисунок). 


\section{Внешние условия (география и социосфера) External conditions (geography and sociosphere)}

- социально-экономические: уровень экономического развития, доходов и образованности населения, уровень доходов населения, место, роль и охват влияние традиционных и новых медиа/socio-economic: level of economic development, income and education of the population, income level of the population, place, role and coverage influence of traditional and new media;

- социокультурные: реальная роль и авторитет интеллектуальных сетей, обычаев и традиций, усредненное восприятие институтов власти/sociocultural: the real role and authority of smart grids, customs and traditions, the average perception of government institutions;

- институииональные: конституциональные требования, соответствие законодательных норм требованиям современного (т. н. цивилизованного) мира, прозрачность голосования/ограничения на участие в политической жизни широких масс населения, уровень сформированности гражданского общества, отношение к оппозиции, легитимность и реальная практика функционирования институтов, вовлеченность в политическое участие, развитость правосознания и идеологическая поляризация граждан/institutional: constitutional requirements, compliance of legislative norms with the requirements of the modern (so-called "civilized") world, transparency of voting/restrictions on participation in political life of the broad masses of the population, level of formation of civil society, attitude to the opposition, legitimacy and real practice of functioning of institutions, involvement in political participation, development of legal consciousness and ideological polarization of citizens.

\section{Политико-правовой институт Political and legal Institute}

• определение порядка формальных социальных взаимодействий и векторов процессов в части принятия решений (по сферам общественной жизни), использования ресурсов, идеологических (идейных) и социальных аттрибутов и т. д.

- determination of the order of formal social interactions and vectors of processes in terms of decision-making (in the spheres of public life) and using resources, ideological (ideas) and social attributes, etc.

\section{Конечные результаты (социальная эволюция)} Outcomes (social evolution)

•поведение акторов направляется на достижение целей по сферам жизнедеятельности/the behavior of actors is aimed at achieving goals in the spheres of life;

- активность, направленная на адаптацию к существующим условиям/изменение данных условий activity aimed at adaptation to existing conditions/change of these conditions.

Рисунок. Модель политико-правового института

(за основу взята модель У. Кротти)

Figure. Model of Political and Legal Institute (the model of W. Crotty is taken as a basis) 
Как отражает приведенная модель, на воплощение политико-правовых институтов, являющихся воплощением продуцируемых интеллектуалами идей, огромное влияние оказывает социосфера. Отмеченные в модели детерминанты формируются в конкретном культурно-историческом контексте, что и приводит к существенным отличиям в практиках функционирования национально определяемых политико-правовых институтов. Для институционального порядка и социальной эволюции конкретных обществ нет стопроцентно одинаковых рецептов, поскольку результаты властной деятельности всегда сочетают в себе общие и дифференцированные признаки. Вся ситуация для проведения адекватного философского анализ аполитико-правовых институциональных трансформаций усложняется еще и их динамичностью, которая заложена в саму природу институтов, диктующая им необходимость эволюционных изменений, как обновление под актуальные проблемы, возникающие в условиях глобализирующейся действительности. На протяжении своего исторического развития политико-правовые институции и тесно связанные с ними социальные конструкты, которые определяют национальную идентичность, ценности и способы осмысления мира (язык, религия, общественные организации), выступают основным инструментальным ресурсом для выживания общества. Действительно, следует признать, что вся история человечества, начиная от древнейших цивилизаций и до образования новых государств даже в реалиях современного и актуального облика мира, всецело завязана на бесконечных траекториях решений субъектов власти.

Осознавая несовершенство современной миросистемы, зарубежные авторы выявляют многочисленные кризисные явления и неопределенности в современных национальных государствах. Более того, существующая социальная архитектура не способна обеспечить решение абсолютно всех проблем на институциональном уровне отдельного государства, ведь любые вновь появляющиеся затруднения сами по себе умножают риски ввиду развития национальных обществ, что де-факто означает перманентность политико-правовых институциональных трансформаций. Дихотомический способ классификации изменений позволяет маркировать их в качестве конструктивных и способствующих общественному развитию (технологические инновации, искусство, торговля) либо деструктивных (экологический коллапс, насильственные завоевания, разрушительные войны). Даже появившиеся те национальные государства, которые появились не так давно и, следовательно, установившие (но не всегда отладившие) собственные политико-правовые системы, также подверглись масштабным трансформациям. Онтология этих кардинальных перемен, что уже понятно, связана с непрекращающимся формированием новых вызовов и угроз. И в странах ядра, и полупериферии, и периферии сегодня констатируются усилия властей к улучшению условий жизни. Таким образом, страны, входящие, например, в ОЭСР, сталкиваются с ними, так же как и государства Африки, Латинской Америки, Южной Азии и Ближнего Востока.

Поэтому общая направленность деятельности по международному сотрудничеству приобретает преимущественно продемократический характер и направляется на повышение качества и доступности образования, развитие инфраструктуры, модернизацию здравоохранения, улучшение благосостояния населения. Перечисленные аспекты социальной сферы действительно невозможны без обозначенной политики и соблюдения соответствующих закрепленных на законодательном уровне инициатив. Однако обозначенные вызовы для современных политико-правовых институтов в национальных обществах усугубляются и тем фактом, что актуальная миросистема ориентирована на решение проблем преимущественно в сфере торговли, финансов и экономики, но она не готова к масштабным социальным изменениям, которые бы адекватно отвечали 
потребностям новой социокультурной действительности. М. Вулкок считает, что современные властные институты одновременно являются дорогими (затратными по их ресурсному обеспечению) и малоэффективными (разрыв «теория-практика», что позволяет говорить о некоторой «институциональной девиации»). В то же время в ряде государств причины их низкой эффективности усматриваются Вулкоком в непрофессионализме отдельных специалистов политико-правовой сферы, а также коррупцией и отсутствием реальных сил у гражданского общества [10].

Далее рассмотрим основные направления изучения политико-правовых институтов в контексте философской компаративистики. Так, одним из них является сравнительное изучение конституций различных государств, являющихся политикоправовыми институтами, которые устанавливают и регламентируют порядок осуществления государственной власти. Данные исследования направлены на выявление сходств и различий, присутствующих в национальных конституциях. Помимо этого, философы анализируют причины, по которым одни конституции являются детерминантами успешности государств, а другие - нет. Особую значимость для философской компаративистики представляют последствия (экономические, социальные, культурные, собственно политико-правовые), к которым приводит конституционно закрепленное институциональное устройство. Возрастание интереса к конституциям обусловлено «великой волной конституционных реформ». Целью данного радикального преобразования было построение сильного сообщества за счет связей посредством норм международного права, которое приобрело мировые масштабы и распространилось от регионов Центральной и Восточной Европы до Южной Африки и Латинской Америки в 80-90-х гг. ХХ в. [12].

В общем, конституция определяется как «историческое соглашение и хранилище ценностей» (неактуальные на том или ином этапе исторического развития конституции принято понимать как «памятник права»), «стимулирующая структура, оказывающая влияние на поведение индивидов» [13, с. 360]. Проведя анализ работ зарубежных авторов, на сегодняшний день можно выделить три основных подхода к исследованию национальных конституций:

1. Рассмотрение, каким образом конституции различных стран разрешают наиболее актуальные (по сферам общественной жизни) проблемы, проводя на основе полученных результатов сравнительный анализ отличий в решениях обозначенных проблем с целью репрезентации различий и контрастов [14, с. 635]. Тем не менее приверженцы данного методологического подхода убеждены, что законодательные системы тех или иных обществ, занятые решением схожих проблем, либо решают их разнообразными средствами, либо используют отличный от других стран инструментарий, что и способствует отличиям, даже при таких результатах, которые внешне кажутся очень похожими [15].

2. Фокус делается на постижении так называемого «конституционного замысла» при исследовании логики обновления как самих конституций, так и предметной модернизации политико-правовых институтов (социальная инженерия) в контексте национальных государств после фукуямовского «конца истории». В качестве перечня задач, приоритетное значение которым отводится сторонниками данного подхода, следует указать определение прагматического эффекта, получаемого от социальных преобразований, а также критическое оценивание конституционных реформ [16].

3. Анализ опыта «конституционных заимствований», для лучшего понимания обстоятельств, при которых заимствование конституционных решений другой страны являются целесообразными и оправданными для собственных государственных практик. 
Общим для перечисленных подходов будет являться аспект исследования взаимосвязей между конституционными положениями и политико-правовыми, социальноэкономическими и культурными особенностями различных стран.

Освещая приоритетные области исследований политико-правовых институтов в контексте философской компаративистики, логичным будет переход от национальных конституций к направлению, посвященному выявлению особенностей функционирования политических партий с их привязкой к конкретным регионам. Большинство мыслителей, занятых в данном направлении философской компаративистики, сходятся на понимании того, что политические партии и политическое поведение в целом формируются под влиянием историко-культурного контекста, что и создает отличия в зависимости от национальной и региональной привязки, да еще и на различных этапах исторического развития. В то же время понимание особенностей формирования и функционирования национальных политических партий существенным образом затрудняется не только их высокой численностью в мировых странах, но и прежде всего отсутствием единства в понимании политической партии как таковой.

У. Кротти отмечает, что на этапе становления философской компаративистики политическая партия, как правило, определялась через следующие дефиниции: команда людей, стремящихся посредством выборов / выборным путем получить доступ к государственному аппарату и контролировать власть в течение максимального периода времени (в зависимости от установленного в конституциях срока) [11]; стратегические альянсы, образованные в соответствии с разделяемыми участниками ценностями, для предупреждения и решения множественных конфликтов в конкретном обществе [11]; институционализированные образования, отличающиеся выбранным стилем поведения в зависимости от заявленной миссии [15]. В наиболее общем виде все политические партии подразделяются на так называемые электоральные партии (party-in-theelectorate), партии-организации (party-as-organization), правительственные партии (party-in-the-government) и законодательные партии (party-in-the-legislature) [11].

В зависимости от выбранной роли политические партии преследуют различные цели: участие в борьбе за власть, оказание влияния и обеспечения контроля принятия государственных решений при помощи применения принципиально ненасильственных методов или же вовсе формальное присутствие в условиях их плюрализма. Иначе говоря, в различных странах партии представляют собой отличающиеся по численности социальные группы, которые выражают заявленные в программах интересы (которые довольно часто пересекаются с интересами, декларируемыми другими партиями, но, как правило, различаются по формулировкам) некоторой части населения и влияют на властные структуры с целью продвижения этих интересов.

Несомненно, что имеются существенные различия в аспектах формирования политических партий, а также их роли в реалиях демократических и недемократических обществ. Если в условиях демократического режима организация института партий осуществляется на основании представления электорату кандидатов и последующей работы с общественным мнением, то при недемократических способах государственного устройства все процедуры выглядят менее прозрачными и даже могут замыкаться в рамках одной партии и, соответственно, без привлечения общественности. Сегодня одной из приоритетных функций, которая выполняется партиями во всех странах, является «информационная» (информирование граждан о деятельности правительства). В условиях демократического варианта организации общественного уклада ее реализация включает критическое оценивание деятельности правительства, информирование о продвижении разумных альтернатив со стороны заинтересованных участников и оппо- 
зиции. В недемократических (как правило, однопартийных) системах акцент смещается на решение, принятое сторонниками партии, де-факто навязываемое к поощрению обществом его императивного исполнения. В таком обществе институт партий можно рассмотреть как средство реализации функций СМИ (которые вдобавок могут находиться под цензурой), направленных на простое, т. е. одностороннее, информирование общества о результатах политической деятельности взамен выработки интеллектуальных альтернатив и вовлечению различных групп в активную политическую деятельность.

В то же время во всех способах организации общественной жизни политические партии организовывают коммуникативные взаимодействия между обществом и правительством, являясь относительно гибким инструментом (в зависимости от способности «прочувствовать» настроения электората), при помощи которого даются интерпретации посылок властных акторов различных требований и предложений. В таком аспекте институт партий определяется в качестве формально организованной группы, которая реализует некоторый набор функций, основная цель которых - подготовить население к принятию существующей системы государственного управления и/или вовлечь их инициативы по выработке предложений для решения текущих политических проблем. Укажем, что данный институт заинтересован в продвижении людей на различные государственные должности.

\section{Ценности и политико-правовые институты}

Крайне важно отметить, что исследования по философской компаративистике, посвященные функционированию и трансформациям политико-правовых институтов, затрагивают проблемы ценностей. Сюда можно отнести и такой аспект, как, например, права человека в демократических и недемократических обществах. Однако еще при освещении партийной проблематики необходимым было указать, что к недемократическим относятся такие страны, в которых преобладают традиционные для данного конкретного общества ценности в совокупности с либерально-демократическими аксиологическими конструктами. Это, конечно, не способствует преодолению европо- и американоцентризма, но зато позволяет отметить векторы трансформации ряда государств. Одним из примеров целого недемократического региона может являться Азия, где располагаются развивающиеся страны, а также широкое распространение и поддержку населения имеют идеи фундаментализма.

Организация и проведение кросс-национальных исследований политикоправовых институтов в недемократических странах все чаще приводит к появлению такого словосочетания, как «азиатские ценности», выражающего противопоставление восточных аксиологических конструктов западным. В социально-философском дискурсе современности восприятие и представление результатов исследований ценностноориентированной проблематики заметно отличаются в работах авторов, которые представляют условные регионы, именуемые ввиду географии «Восток» и «Запад». В частности, большинство «восточных» исследователей подчеркивают, что в ситуации крайней бедности и неблагополучия азиатских регионов проблема института прав человека, как и всецелого функционирования политико-правовых институтов, которые бы их обеспечивали, все еще представляется недостаточно актуальной. В качестве лишь одного из аргументов в пользу представленного тезиса можно представить позицию Ли Куан Ю: «Как премьер-министр Сингапура, в качестве первой задачи я обозначаю необходимость выхода страны из деградации, которая сопровождается бедностью, проблемами здравоохранения и обычным невежеством. В таких реалиях нашу страну не 
просто захватила бедность, но и сама человеческая жизнь попросту утратила свою ценность, придав второстепенное значение многим проблемным аспектам общественной жизни» [17]. В восточных странах ввиду ярко выраженной интровертности, консерватизма и традиционализма мышления главенствующая роль принадлежит государству, понимаемому нами в качестве суперинститута.

К примеру, если оппозиционные группы угрожают процессам поступательного экономического развития страны или способны дестабилизировать его социальные устои и привести к общественным беспорядкам, в большинстве азиатских государств власти принимают жесткие меры, которые вне зависимости от их соответствия либерально-демократическим идеалам позволяют стабилизировать возникшую ситуацию. Иначе говоря, в восточной традиции скорее наблюдается оправданность интересов государства, но не личности и ее прав и свобод, что является полной противоположностью для большинства государств Европы и США. Здесь примечательны убеждения сторонников западных ценностей, отмечающих, что множество результатов компаративистских исследований в данном направлении не подтверждают сильные корреляции между авторитаризмом и экономической стабильностью. Хотя, Д.А. Белл указывает, что именно конституционное закрепление и фактическое соблюдение провозглашенных властями гарантий прав и свобод человека обеспечивает социальноэкономическую безопасность государства, позволяя минимизировать риски общественных угроз за счет адекватного современному миру удовлетворения и защиты интересов личности [18].

Следует отметить, что в рамках философской компаративистики представители восточного стиля понимания институтов политики и права не отрицают факта необходимости защиты универсальных ценностей. По своей сути, дискуссия идет не столько о сущности прав человека и потребностях создания новых и обновления существующих политико-правовых институтов, направленных на их обеспечение, сколько о модели их продвижения. Такие паттерны должны учитывать особенности имплементации прав человека и адаптации либерально-демократических ценностей в различные культурные реалии, поскольку правительства такого региона, как, например, Восточная Азия, достаточно часто видят необходимость ограничения определенных прав личности в краткосрочной перспективе для обеспечения других прав в будущем. По сути, это очень напоминает советскую модель общественного устройства, когда люди испытывали существенные лишения и были ограничены в настоящем по причине артикулирования властями устремлений и призывов «строить коммунизм».

Кроме того, в современной научной литературе все чаще отмечается наличие глубокой дифференциации при понимании самих ценностей. С одной стороны, ученые из азиатских стран, как правило, делают акцент на том, что ценности, являющиеся традиционными для восточной цивилизации, ни в чем не уступают западным аксиологическим конструктам, которые при обращении, например, к правам человека, можно обнаружить еще в конфуцианстве [19, с. 399]. С другой стороны, присутствует мнение, подчеркивающее значительную роль религии (прежде всего речь идет об исламе) в ряде азиатских стран. По сути, ислам является основой таких практик, как создание семьи, контроль за процедурами обеспечения неприкосновенности приватной жизни, а также традиционное для большинства мирового населения право на свободу передвижения, использования родного языка и даже вероисповедания [18]. Наше понимание исламского права, фундированного культурой, религией и традициями, позволяет отметить, что оно действительно требует от государства выполнения многочисленных обязательств по обеспечению социально-экономических стандартов жизни, которые можно 
назвать достойными. Другими словами, мы видим, что ценности, которые люди склонны однозначно приписывать азиатским государствам, во многом содержательно могут походить на западные аналоги, а основная разница, как обычно, заключается в их интерпретациях.

Вместе с тем в странах азиатских регионов посредством комплексного анализа их богатой истории можно обнаружить факты наличия и функционирования политикоправовых институтов, практики которых организованы с целью защиты рассматриваемых прав и ценностей. В частности, идея сдерживания безграничной власти правителей также обнаруживается, например, в древнекитайской философии, в которой предлагается создание особых цензов для своего рода «допуска» к осуществлению власти. Структура государственного управления в Древнем Китае представлена тремя властными органами, созданными не только для осуществления судебных и контролирующих функций, но также в связи с предоставлением, например, избирательных прав представителям оппозиции и неорганизованным в какие-либо объединения индивидам, которые попросту не согласны с политикой, осуществляемой текущим правлением. Даже в древней истории, не говоря уже об эпохе Нового времени, можно обнаружить прототипы, напоминающие типы современного государственного устройства. Также необходимо отметить, что в китайском социально-философском наследии можно увидеть аналоги современных социально-экономических прав (к примеру, поддержка малообеспеченных слоев населения) [18].

Итак, возникает логичный вопрос: настолько ли универсальны ценности западной либерально-демократической традиции и стоит ли всем странам Азии создавать политико-правовые институты, опираясь лишь на данные аксиологические основания? Гораздо целесообразнее осуществлять модернизационные институциональные преобразования, воплощая на практике те или иные идеи в соответствии с собственными культурными моделями в их синтезе с либерально-демократическими ценностями, адаптированными под национальную практику. Обращение к западной мысли и акцентуация властями случаев открытой имплементации ее идей в различных модификациях и конфигурациях оправдывается в зависимости от целей и задач, которые возникают перед государством.

Общеизвестно, что нововременная Европа стала той «социосферой» [20], где интеллектуалами вырабатывались эволюционные идеи, которые по умолчанию присутствуют, но где-то попросту не проявляются во властных практиках большинства государств. В целом необходимость учета контекста осуществления институциональных преобразований подтверждается большинством исследователей, занимающихся изучением особенностей современного мирового развития. Их взгляды сходятся в понимании того, что оптимизация государственного устройства не всегда связана с принятием и продвижением какой-либо универсальной конфигурации ценностей (так называемого «рецепта»), поскольку ее реализация возможна только при отборе и соединении идей, не обнаруживающих конфронтаций между их содержанием и интересами большинства местного населения [18]. В то же время коллеги считают очевидным, что сегодня невозможно отрицать совместимость либерально-демократических идей с традициями и представлениями многочисленного населения азиатского региона о желаемом государстве. Этот подход в полной мере подтверждает нашу убежденность в том, что современные государства априори испытывают зависимость от встречающихся у европейских философов «стандартов» в аспектах вариаций государственного устройства, в частности модернизации существующих и создании новых политико-правовых институтов.

По мнению автора, ошибочными являются мнения, которые предлагают пессимистичный взгляд на обращение к использованию опыта западных демократий, которые 
якобы обязательно повлекут за собой только негативные последствия. Такие радикальные взгляды на практику осуществления модернизационных преобразований институтов в сфере политики и права играют на руку исключительно противникам западного либерализма. Приведенная позиция обращает внимание на некоторую эрозию аксиологических оснований либерально-демократических идей в части политико-правового институционального оформления государства. Ее стандартная формулировка может быть оценена не иначе, как «американоцентристская», что выглядит излишне редуцированно, поскольку при всей мощи США содержание современной западной мысли не может исключать Европу и Японию.

Итак, «пессимисты» заявляют, что если после Второй мировой войны США обладали достаточной силой для навязывания собственных ценностей, а также для прямого участия в социальных преобразованиях конкретных государств, то сегодня на мировой арене отмечается падение авторитета Соединенных Штатов. Они отмечают, что главный ущерб авторитету США нанесли себе сами - и это выражается в проводимом курсе внешней политики и многочисленных военных вторжениях, результатом чего становится восприятие либерально-демократических идей как циничных и ложных. Тем не менее такой подход вовсе не обращает внимания на уже упомянутые страны Европы, поэтому в силу одностороннего редуцированного видения проблемы не может претендовать на то, чтобы называться философским.

Однако позитивным маркером этого подхода становится обращение внимания на страны, которые становятся «новыми точками роста», куда исследователи относят, к примеру, государства, входящие в БРИКС, ШОС, а также Австралию. Одним из примеров критического отношения к так называемым «американским» ценностям является теория О. Ясуаки, утверждающего, что такая позиция государства, сопряженная, прежде всего с ярко выраженным индивидуализмом, влечет за собой множество социальных проблем. К наиболее значимым этот ученый относит наркотизацию общества, распад семей, рост преступности, увеличение экономического неравенства, социальную несправедливость и т.д. [21]. Вторым аспектом, с которым наша позиция совпадает со взглядами «пессимистов», является их убежденность, что формирование политикоправовых институтов исключительно по западным образцам не будет успешным, является абстрактность данных ценностей для местного населения, что также затрудняет их понимание и, как следствие, не позволяет в достаточной мере реализовать функционал данных социальных структур [18].

Важно добавить, синтез традиций и западных ценностей позволяет организовать успешное функционирование современных политико-правовых институтов, среди которых значимая роль принадлежит многочисленным неправительственным организациям, а также социальным установлениям, практики которых направлены на защиту прав женщин. Подобные объединения активно участвуют в политической жизни страны и утверждают, что на протяжении столетий ислам несколько ошибочно использовался для установления патриархального уклада. В частности, неправительственная организация «SistersinIslam» разработала для Малайзии меморандум с призывом осуществить реформу, суть которой нашла бы свое отражение в пересмотре системы наказаний за совершаемые преступления [18]. Эта же организация занимается информированием посредством распространения брошюр с описанием прав и обязанностей мужчин и женщин в семье, стремясь тем самым к достижению такой цели, которой бы стало фактическое закрепление и обеспечение гендерного равноправия. Ощутимым сдвигом, подтверждающим факты реализации продвигаемых данными организациями идей, ста- 
новятся реформы политико-правовых институтов, обусловливающих выход на новый уровень взаимодействий общества и государства в целом.

Ученые подчеркивают неодинаковость в понимании прав и свобод граждан в различных странах. Такой факт означает, что западные политико-правовые концепции могут трактоваться как «слишком широкие» по предмету своего регулирования, но в некоторых государствах они могут быть и «узкими». В частности, видный тайский активист Sulak Sivaraksa подчеркивал, что он выступает за демократизацию общества и последующее обновление политико-правовых институтов, которые позволят гарантировать права личности на свободу слова как одну из базовых ценностей европейского общества при одновременном осуждении любых нападений на персону короля. В то же время общеизвестно, что в странах Европы и США критика властей и первых лиц государств - привычная практика, а трансформация статуса СМИ уже позволяет считать их в качестве одного из наиболее влиятельных политико-правовых институтов современности. Итак, с одной стороны, Sulak Sivaraksa поддерживает демократизацию существующего институционального порядка, с другой - предлагает осуществлять предметную и пошаговую модернизацию в духе социальной инженерии, ведь в подобном случае реформирование пройдет более плавно и с меньшими затратами, поскольку не встретит культурного сопротивления и не разрушит полностью существующий институциональный порядок $[18,22]$. Таково проявление частичного принятия либеральнодемократических ценностных оснований политико-правовых идей.

В философской компаративистике изучение политико-правовых институтов проводится не только через противопоставление демократических обществ недемократическим, но и, к примеру, через сопоставление институтов в самих демократических странах. В последние годы, ввиду отмечаемой специалистами эффективности государственного устройства и функционирования институтов, отмечается рост числа работ, посвященных сравнению данных социальных установлений в странах скандинавского региона. Анализируя причины успешности создания демократических институтов в Скандинавии, исследователи обращаются к недавнему историческому прошлому, подчеркивая факт заимствования идей и ценностей у стран Востока и Запада. Так, исследователи указывают, что на сегодняшний день нескандинавским странам следует синтезировать и реализовывать идеи Востока и Запада.

Логичной выглядит практическая рекомендация J. Strang и J. Kurunmäki, что Pocсии и США следует обратиться к опыту «северных демократий», которые сегодня выступают реальными борцами за мир, свободу, проведение всесторонней социальной политики «в хаотическом и психически ненормальном мире» [23, с. 45]. Таким образом, в сегодняшнем контексте скандинавских стран властям удалось объединить западные интеллектуальные конструкты, связанные в первую очередь с правами и свободами граждан, с идеалами восточных теорий, касающихся равенства. Современные философы указывают, что политико-правовые институты в государствах Скандинавии основываются на демократических принципах, однако в отличие от большинства европейских стран здесь демократия нашла свое отражение не только в форме устройства государства, правительства. Данные принципы де-факто пронизывают все аспекты жизнедеятельности общества, создавая сильные связи между элементами социальной системы. Вообще надежность данной демократической модели усматривается в поддержке населения этих стран, которые, что важно, воспринимают принципы народовластия в качестве средства гармонизации отношений между обществом и человеком в усложняющемся современном мире. 


\section{Заключение}

На основании проведенного исследования становится понятно, что философская компаративистика представляет собой междисциплинарную область современного научного знания, сформированную на множестве наук (юриспруденции, политологии, социологии, культурологии, истории и т. д.). В центре внимания данной области - сопоставительное/сравнительное исследование самых различных аспектов функционирования национальных обществ и государств с целью их лучшего понимания, преодоления европоцентризма, сохранения полифонии национальных наук и культур.

В последние десятилетия ввиду усложнения общепланетарного бытия злободневным становится сравнительное изучение особенностей формирования и функционирования политико-правовых институтов в разных странах по причине их особой роли в обеспечении социального порядка. Проведенный анализ отражает, что на сегодняшний день политико-правовые институты в контексте философской компаративистики, как правило, нацелены на изучение особенностей создания политических партий и их роли в жизнедеятельности конкретных обществ; на выявление общего и различного в национальных конституциях, обуславливающих особенности конструирования политического устройства национальных государств. Также сопоставительные исследования могут проводиться между демократическими и недемократическими странами, между странами Запада и странами Востока, а также вообще между странами какого-либо одного режима.

В результате проведенного анализа исследований зарубежных ученых можно указать на общность их взглядов в части того, что политико-правовые институты в различных государствах наиболее эффективно функционируют при учете актуального контекста и, конечно, национальных ценностей, представлений и идеалов. Аксиологические основания вплетаемых в социальную ткань идей действительно существенно отличаются, соответственно, создаются модификации и конфигурации интеллектуальных конструктов, фундирующих политико-правовые институты. В то же время такие выводы делают очевидным отсутствие универсального рецепта ценностей. Таким образом, актуализация проблемы обновления политико-правовых институциональных практик в философской компаративистике призвана решить такую задачу, которая бы позволила государствам обеспечить оптимальное взаимодействие на всех уровнях социального бытия.

\section{СПИСОК ЛИТЕРАТУРЫ}

1. Береговая О.А. Философская компаративистика и компаративная философия образования// Исторические, философские, политические и юридические науки, культурология и искусствоведение. Вопросы теории и практики. - 2016. - № 9 (71). - С. 17-19.

2. Dallmayr F. Introduction: toward a comparative political theory // The Review of Politics. - 1997. № 59 (3). - P. 421-427.

3. Dallmayr F. Beyond monologue: for a comparative political theory // Perspectives on Politics. - 2004. № 2. - V. 2. - P. 249-257.

4. Колесников А.С. Методология компаративистского изучения философии и культуры Востока // Вестник Русской христианской гуманитарной академии. - 2008. - Т. 9. - № 1. - С. 19-29.

5. Дискин И.Е. Институты: загадка и судьба. - М.: РОССПЭН, 2016. - 302 с.

6. Панов П.В. Институты, идентичности, практики: теоретическая модель политического порядка. - М.: Российская политическая энциклопедия (РОССПЭН), 2011. - 230 с.

7. Норт Д. Институты, институциональные изменения и функционирование экономики. - М.: Фонд экономической книги «Начала», 1997. - 180 с.

8. Кириченко И.В. Национально-культурные основания политико-правового управления // Философия права. - 2008. - № 1. - С. 138-141. 
9. Равочкин Н.Н. Переход Европы от средневекового общества к индустриальному: социальнофилософский анализ // Социодинамика. - 2019. - № $6 . \quad$ - C. 123-130. URL: https://nbpublish.com/library_read_article.php?id=29908 (дата обращения 01.10.2019). DOI: 10.25136/2409-7144.2019.6.29908.

10. Woolcock M. Social institutions and the development process: using cross-disciplinary insights to build an alternative aid architecture // Polymath: An Interdisciplinary Arts and Sciences Journal. - 2017. - № 7 (2). P. 5-30.

11. Crotty W.J. A Perspective for the comparative analysis of political parties // Comparative Political Studies. - 1970. - №3. - P. 267-296.

12. Jackson V.C., Tushnet M.V. Defining the Field of Comparative Constitutional Law. - Westport, CT: Praeger, 2002. $-296 \mathrm{p}$.

13. Cooter R.D. The strategic constitution. - NJ: Princeton University Press, 2000. -440 p.

14. Whytock C. A. Taking causality seriously// Comparative Constitutional Law: Insights from Comparative Politics and Comparative Political Economy. - 2008. - № 7. - V. 41. - P. 629-682.

15. Zweigert K., Kötz H. An Introduction to Comparative Law. - Oxford: Oxford University Press, 1998. $744 \mathrm{p}$.

16. Cass S. Designing Democracy: What Constitutions Do. - Oxford: Oxford University Press, 2002. - 292 p.

17. My Interview with Lee Kuan Yew. URL: https://www.asiapacific.ca/blog/my-interview-lee-kuan-yew (дата обращения 01.10.2019).

18. Bell D.A. Beyond liberal democracy: political thinking for an East Asian context. - NJ: Princeton University Press, 2006. - 408 p.

19. Bell D.A. Human rights and social criticism in contemporary Chinese political theory // Political Theory. 2004. - № 3. - V. 32. - P. 397-400.

20. Розов Н.С. Идеи и интеллектуалы в потоке истории: макросоциология философии, науки и образования. - Новосибирск: Манускрипт, 2016. - 344 с.

21. Bauer J.R., Bell D.A. The East Asian challenge for human rights. - NY: Cambridge University Press, 1999. - 412 p.

22. Bell D.A., Hahm C. Confucianism for the modern world. - NY: Cambridge University Press, 2003. - 398 p.

23. Strang J., Kurunmäki J. Nordic democracy as a model-building concept ideas, society and politics // Ideas, Society and Politics in Northeast Asia and Northern Europe: Worlds Apart, Learning from each other / Ed. by R.T. Nielsen, G. Helgesen. - Leifsgade: NIAS Press, 2012. - P. 39-52. URL: https://www.divaportal.org/smash/get/diva2:876650/FULLTEXT01.pdf (дата обращения 01.10.2019).

Поступила 17.10.2019 2. 


\title{
PROBLEMS OF POLITICAL AND LEGAL INSTITUTIONS IN THE CONTEXT OF MODERN PHILOSOPHICAL COMPARATIVE STUDIES
}

\author{
Nikita N. Ravochkin, \\ nickravochkin@mail.ru
}

Kemerovo State Agricultural Institute, 5, Markovtsev street, Kemerovo, 650056, Russia.

Nikita N. Ravochkin, Cand. Sc., associate professor, Kemerovo State Agricultural Institute.

This article discusses the problems of political and legal institutions in the context of research related to a relatively new section of scientific knowledge - philosophical comparative studies. The relevance of the study is confirmed by the high level of responsibility that rests with the institutions in question in order to ensure their social order. Thus, the comparative studies look extremely necessary when studying the ideological determination of similar institutions in various types of society and state. The subject of the research is promising areas for comparative studies of modern political and legal institutions. The object of the research is modern political and legal institutions. The aim of the study was to identify the field of problems of political and legal institutions in the context of studies on philosophical comparative studies. To achieve this goal, the author uses his own synthetic methodology, including general scientific, philosophical and interdisciplinary methods (actor-network theory, memetics, world-system approach, social realism). The paper introduces the definitions of philosophical comparative studies. The political and legal institutions are included in this section, for which the author proposes his own model of political and legal institutions, complementing the model of W. Crotty. The main directions of research of political and legal institutions: the problems of parties, constitutions, values with reference to various states and regions, are outlined.

Keywords: Political and legal institute, ideas, philosophical comparative studies, values, society, state, world.

\section{REFERENCES}

1. Beregovaya O.A. Philosophical comparative studies and comparative philosophy of education. Historical, Philosophical, Political and Law Sciences, Culturology and Study of Art. Issues of Theory and Practice, 2016, no. 9 (71), pp. 17-19. In Rus.

2. Dallmayr F. Introduction: toward a comparative political theory. The Review of Politics, 1997, no. 59 (3), pp. 421-427.

3. Dallmayr F. Beyond monologue: for a comparative political theory. Perspectives on Politics, 2004, no. 2, vol. 2, pp. 249-257.

4. Kolesnikov A.S. Methodology of the comparative study of the philosophy and culture of the East. Herald of the Russian Christian Academy for humanities, 2008, vol. 9, no. 1, pp. 19-29. In Rus.

5. Diskin I.E. Instituty: zagadka $i$ sudba [Institutes: riddle and fate]. Moscow, ROSSPEN Publ., 2016. 302 p.

6. Panov P.V. Instituty, identichnosti, praktiki: teoreticheskaya model politicheskogo poryadka [Institutions, identities, practices: theoretical model of the political order]. Moscow, Rossiyskaya politicheskaya entsiklopediya Publ., 2011. 230 p.

7. Nort D. Instituty, institutsionalnye izmeneniya i funktsionirovanie ekonomiki [Institutions, institutional change and the functioning of the economy]. Moscow, Fond ekonomicheskoy knigi «Nachala» Publ., 1997. $180 \mathrm{p}$.

8. Kirichenko I.V. National-cultural foundations of political and legal management. Philosophy of Law, 2008, no. 1, pp. 138-141. In Rus.

9. Ravochkin N.N. The transition of Europe from medieval to industrial society: socio-philosophical analysis. Sotsiodinamika, 2019, no. 6, pp. 123-130. In Rus. Available at: https://nbpublish.com/library_ read_article.php?id=29908 (accessed 1 October 2019). DOI: 10.25136/2409-7144.2019.6.29908. 
10. Woolcock M. Social institutions and the development process: Using cross-disciplinary insights to build an alternative aid architecture. Polymath: an Interdisciplinary Arts and Sciences Journal, 2017, no. 7 (2), pp. 5-30.

11. Crotty W.J. A Perspective for the Comparative Analysis of Political Parties. Comparative Political Studies, 1970, no. 3, pp. 267-296.

12. Jackson V.C., Tushnet M.V. Defining the field of comparative constitutional law. Westport, CT, Praeger, $2002.296 \mathrm{p}$.

13. Cooter R.D. The strategic constitution. NJ, Princeton University Press, 2000. $440 \mathrm{p}$.

14. Whytock C.A. Taking causality seriously. Comparative Constitutional Law: Insights from Comparative Politics and Comparative Political Economy, 2008, no. 7, vol. 41, pp. 629-682.

15. Zweigert K., Kötz H. An introduction to comparative law. Oxford, Oxford University Press, 1998. 744 p.

16. Cass S. Designing democracy: What constitutions do. Oxford, Oxford University Press, $2002.292 \mathrm{p}$.

17. My Interview with Lee Kuan Yew. Available at: https://www.asiapacific.ca/blog/my-interview-lee-kuanyew (accessed: 1 January 2019).

18. Bell D.A. Beyond liberal democracy: political thinking for an East Asian context. NJ, Princeton University Press, 2006.408 p.

19. Bell D.A. Human rights and social criticism in contemporary Chinese political theory. Political Theory, 2004, no. 3, vol. 32, pp. 397-400.

20. Rozov N.S. Idei $i$ intellektualy v potoke istorii: makrosotsiologiya filosofii, nauki i obrazovaniya [Ideas and intellectuals in the stream of history: macro-sociology of philosophy, science and education]. Novosibirsk, Manuskript Publ., 2016. 344 p.

21. Bauer J.R., Bell D.A. The East Asian challenge for human rights. NY, Cambridge University Press, 1999. $412 \mathrm{p}$.

22. Bell D.A., Hahm C. Confucianism for the modern world. NY, Cambridge University Press, 2003.398 p.

23. Strang J., Kurunmäki J. Nordic democracy as a model-building concept ideas, society and politics. Ideas, Society and Politics in Northeast Asia and Northern Europe: Worlds Apart, Learning from each other. Eds. R.T. Nielsen, G. Helgesen. Leifsgade, NIAS Press, 2012. pp. 39-52. Available at: https://www.divaportal.org/smash/get/diva2:876650/FULLTEXT01.pdf (accessed 1 January 2019).

Received: 17 October 2019. 